\begin{tabular}{|l|c|c|c|c|}
\hline $\begin{array}{l}\text { Cuadernos de Investigación Geográfica } \\
\text { Geographical Research Letters }\end{array}$ & 2019 & N $^{\circ} 45(1)$ & pp. 271-286 & eISSN 1697-9540 \\
\hline
\end{tabular}

\title{
LONG-TERM ORGANIC FARMING ON A CITRUS PLANTATION RESULTS IN SOIL ORGANIC CARBON RECOVERY
}

\author{
A. NOVARA ${ }^{1 *}$, M. PULIDO ${ }^{2}$, J. RODRIGO-COMINO ${ }^{3}$, S. DI PRIMA ${ }^{4}$, P. SMITH ${ }^{5}$, L. $^{2}$ \\ GRISTINA $^{1}$, A. GIMÉNEZ-MORERA ${ }^{6}$, E. TEROL ${ }^{7}$, D. SALESA ${ }^{8}$, S. KEESSTRA $^{9,10}$
}

${ }^{1}$ Dipartimento di Scienze Agrarie, Alimentari e Forestali, University of Palermo,viale delle Scienze, ed.4, 90128 Palermo (Italy).

${ }^{2}$ GeoEnvironmental Research Group, University of Extremadura, Faculty of Philosophy and Letters, Avda. de la Universidad s/n, 10071 Cáceres, Spain. ${ }^{3}$ Instituto de Geomorfología y Suelos, Department of Geography, University of Málaga, Edificio Ada Byron, Ampliación del Campus de Teatinos, 29071 Málaga, Spain. ${ }^{4}$ Université de Lyon; UMR5023 Ecologie des Hydrosystèmes Naturels et Anthropisés, CNRS, ENTPE, Université Lyon 1, 3 rue Maurice Audin, 69518 Vaulx-en-Velin, France.

${ }^{5}$ Institute of Biological \& Environmental Science, University of Aberdeen, 23 St Machar Drive, Aberdeen AB24 3UU, United Kingdom.

${ }^{6}$ Department of Economy and Social Sciences, Universitat Politècnica de València, Camino de Vera s/n, 46022 Valencia, Spain.

${ }^{7}$ Department of Cartographic Engineering, Geodesy and Photogrammetry, Universitat Politècnica de València, Camino de Vera s/n, 46022 Valencia, Spain.

${ }^{8}$ Soil Erosion and Degradation Research Group, Department of Geography, Universitat de València, Blasco Ibañez, 28, 46010 Valencia, Spain.

${ }^{9}$ Team Soil, Water and Land Use, Wageningen University Research, Droevendaalsesteeg 3, 6708PB Wageningen, The Netherlands

${ }^{10}$ Civil, Surveying and Environmental Engineering, The University of Newcastle, Callaghan 2308, Australia.

\begin{abstract}
It has been shown that soil management under organic farming can enhance soil organic carbon, thereby mitigating atmospheric greenhouse gas increases, but until now quantitative evaluations based on long term experiments are scarce, especially under Mediterranean conditions. Changes in soil organic carbon (SOC) content were examined in response to organic management with cover crops in a Mediterranean citrus plantation using 21 years of survey data. Soil organic carbon increase was more apparent 5 years after a land management change suggesting that, for citrus plantations on Mediterranean conditions, studies should be longer than five years in duration. Soil organic carbon sequestration rate did not significantly change

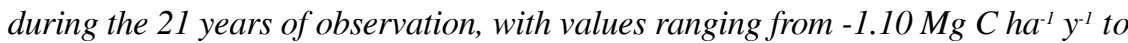
$1.89 \mathrm{Mg} \mathrm{Cha}^{-1} \mathrm{y}^{-1}$. After 21 years, $61 \mathrm{Mg} \mathrm{CO}_{2} \mathrm{ha}^{-1}$ were sequestered in longlived soil $C$ pools. These findings demonstrate that organic management is an effective strategy to restore or increase SOC content in Mediterranean citrus systems.
\end{abstract}




\section{La agricultura ecológica a largo plazo en plantaciones de cítricos permite la recuperación del carbono orgánico del suelo}

RESUMEN: Se ha demostrado que el manejo del suelo bajo agricultura ecológica puede aumentar el contenido de carbono orgánico en el suelo moderando el incremento de los gases de efecto invernadero, pero hasta la fecha las evaluaciones cuantitativas basadas en mediciones a largo plazo han sido escasas, especialmente bajo condiciones mediterráneas. En esta investigación se examinaron los cambios en el contenido de carbono orgánico como respuesta a la agricultura ecológica con cobertura vegetal en una plantación de cítricos en el área mediterránea, utilizando una base de datos de 21 años. El incremento de contenido de carbono orgánico en el suelo fue más evidente tras cinco años desde el cambio del manejo del suelo, sugiriendo que, para plantaciones de cítricos en ambientes mediterráneos, los estudios deberían tener una duración superior a cinco años. La sata de secuestro de carbono orgánico no cambió significativamente durante los 21 años de observaciones, con valores que oscilaron entre - $1.10 \mathrm{MgC} \mathrm{ha}^{-1} \mathrm{a}^{-1}$ y $1.89 \mathrm{Mg} \mathrm{Chal}^{-1} \mathrm{a}^{-1}$. Tras 21 años, un total de 61 t $\mathrm{CO}_{2} \mathrm{ha}^{-1}$ fueron secuestradas en las áreas de acumulación de carbono en el suelo. Estos resultados demuestran que la agricultura ecológica es una estrategia efectiva para restaurar o incrementar los niveles de carbono orgánico en el suelo en los sistemas de cítricos mediterráneos.

Key words: Organic carbon, citrus, long-term experiment, carbon sequestration rate.

Palabras clave: Carbono orgánico, cítricos, experimento a largo plazo, tasa de secuestro de carbono.

Received: 1 November 2018 Accepted: 13 December 2018

*Corresponding author: Agata Novara, Dipartimento di Scienze Agrarie, Alimentari e Forestali, University of Palermo, viale delle Scienze, ed.4, 90128 Palermo (Italy). E-mail address: agata.novara@unipa.it

\section{Introduction}

Organic farming has been suggested as a potential solution to achieve sustainable agriculture management given some of the hazards and environmental damage caused by the widespread use of agro-chemicals in the Green Revolution during the 20 $0^{\text {th }}$ century (Benbrook and McCullum-Gómez, 2009; Argyropoulos et al., 2013; Seufert et al., 2017). Organic farming is a strategy based in the use of natural products to achieve sustainable agriculture (Rigby and Cáceres, 2001). Organic farming is based in the natural cycles of nutrients, and avoids any use of chemicals that damage life, soils, water and air quality and is accepted even more widely by stakeholders (Michelsen, 2001). Organic farming can be practiced on any crop, and 
in vineyards can help to achieve sustainable management (Kapović Solomun et al., 2018; Wang et al., 2018).

Soils are a key component of the Earth system as they mediate hydrological, erosional, biological and geochemical cycles (Davidson and Janssens, 2006; Gruber and Galloway, 2008). The importance of soils in the Earth system is widely recognized, and they underpin the delivery of many of the United Nations Sustainable Development Goals (Keesstra et al., 2016a). Preserving soil is essential for sustainability, as soils provide vital functions to plants and animals, produce food, biomass and raw materials, habitat, maintain the gene pool, the carbon sink, and manage water, minerals and nutrient cycles (Smith et al., 2015). The United Nations highlighted that soil protection is a key land-use policy issue and there is a need to develop strategies to maintain soil quality, soil functions and services to achieve sustainability (Keesstra et al., 2016b, 2018; Panagos et al., 2016; Paleari, 2017).

Previous research demonstrated that organic farming can improve soil quality, from a physical, chemical and biological point of view. Natural soil fertility can be enhanced by organic farming (Maeder et al., 2002) and organic farming promotes below- and above-ground biota (Birkhofer et al., 2008). A comparison of organic and conventional farming systems shows that the soil organic carbon (SOC) content and soil biology indicators were greater after 21 years of organic farming (Fließbach et al., 2007). Different chemical and biological indicators demonstrated the positive impact of organic farming systems in Central Italy (Marinari et al., 2006). Glover et al. (2000) applied a systematic rating method to determine soil quality in conventional, organic and integrated apple orchards, and Liebig and Doran (1999) measured the impact of organic practices on soil quality indicators. Schjonning et al. (2002) found that soil organic carbon increased in quality in humid sandy loam soils under organic agriculture. Most of these changes occur because organic farming improves soil fauna (Crittenden et al., 2014) and natural soil fertility (Bowles et al., 2014). Organic farming reduces soil losses and promotes the use of catch crops, mulches, weeds or chipped pruned branches (Kirchhoff et al., 2017; Cerdà et al., 2018a). Increased plant and litter input reduces losses of soil and SOC, and promotes soil fertility and soil resilience. This impact is based in the increase in SOC, which underpins many positive soil characteristics (Smith et al., 2015). Macilwain (2004) suggests that organic farming can be the future solution for the improvement of agroecosystems. Organic farming also encourages natural pest control (Crowder et al., 2010), and will likely improve agricultural sustainability (Reganold et al., 2001). It has also been suggested that organic farming can transform agricultural soils into a sink of carbon as a way to reduce global warming (Skinner et al., 2014). This idea has attracted political attention since 2016, when a new international initiative was launched by France to mitigate climate change by sequestering carbon in the form of SOC. It was argued that an additional 4 parts per thousand, or " 4 per mille" of SOC per year would help reach the French climate change mitigation target and this is based on the high capacity that degraded soils have to sequester SOC (Averill et al., 2014; Fujisaki et al., 2015; Lehmann and Kleber, 2015). 
Changes in SOC triggered by organic farming have been widely studied in temperate climates (Sommer and Bossio, 2014; Catalán et al., 2016; Smith, 2016), but little is known in arid and semiarid climatic conditions. This is also true for the Mediterranean region which produces large amounts of citrus, vine, grapes, olive oil, fruits and vegetables that need a healthy soil with sufficient nutrients, normally supplied by the soil organic matter (Lugato et al., 2014; Álvaro-Fuentes et al., 2014; Schillaci et al., 2017). However, due to intensive production over centuries, most soils are depleted in natural organic matter (Borrelli et al., 2016; Montanaro et al., 2017; Novara et al., 2017). The current citrus production in Eastern Spain is modern, technical and uses large inputs of agrochemicals, and induce high erosion rates (Cerdà et al., 2009) and low infiltration rates (Di Prima et al., 2018). These systems need strategies to reduce the soil losses (Cerdà et al., 2018b, 2018c; Keesstra et al., 2019) and improve soil quality (Hondebrink et al., 2017).

Citrus has been grown since the $19^{\text {th }}$ century, and due to rising market prices in Europe, they were among the first systems to use seabird guano (manure) from Peru and natural Chilean sodium nitrate (Chile Saltpetre) for fertilization, though soon after, chemical fertilizers were introduced. Next to the success of the conventional citrus plantation, the development of the European Union regulations and incentives for organic farming in the 1990s resulted in the growth of organic farming, which now accounts for $3 \%$ of the citrus land, and is expected to grow in future due to favourable markets for organic products. The growth in organic citrus farming is an opportunity to increase the amount of carbon stored in the soil system and to reduce atmospheric $\mathrm{CO}_{2}$, thereby contributing to the mitigation of climate change. Long-term measurements are necessary to understand the behaviour of natural systems (Novara et al., 2019). To determine the evolution of soil carbon content, we measured SOC content in citrus orchards between 1995 and 2016. These long term measurements shed light on the evolution of SOC and the impact of land management on ecosystem services via carbon sequestration useful to provide information for establishing incentives, guidelines and environmental policies. Therefore, the aim of this study is to examine, under field conditions, the long-term changes of SOC under organic farming management in citrus orchards in a Mediterranean environment.

\section{Material and methods}

\subsection{Study area and experimental design}

This research was carried out at the Alcoleja Experimental Station located in the Cànyoles river watershed in Eastern Spain (UTM: 709191X, 4316356Y; Zone 30), at 156 m.a.s.1.. The climate is Mediterranean with a mean annual precipitation of $545 \mathrm{~mm}$ and a mean annual temperature of $16{ }^{\circ} \mathrm{C}$. The soil is a Xerorthent (Soil Survey Staff, 2014). The texture of the soil is a clay-loam, consisting of $19.8 \%$ clay, $42.1 \%$ silt, and $38.0 \%$ sand. A 1 ha research plot was selected with orange plantations (45 years old) of the Naveline variety (rootstock Cleopatra). The trees are planted at $5 \times 4 \mathrm{~m}$ in distance and the plot is irrigated by flooding in summer every 21 days and during drought periods. The irrigation water comes 
from a natural spring (Riu de Sants), though in summer, the water is pumped from the same aquifer when there is a shortage in the river discharge, which has been frequent since the 1980s due to aquifer depletion. The spring supplies the discharge for the irrigation and is $2 \mathrm{~km}$ from the experimental station. The studied soil was managed as a conventional (chemical) farm from the 1960s until 1994, when the orange trees were planted. Since 1995, organic farming management has been applied, with chipped pruned branches and weeds, and manure from sheep at an application rate of $15 \mathrm{Mg} \mathrm{ha}^{-1}\left(0.06 \% \mathrm{~N}, 0.02 \% \mathrm{P}_{2} \mathrm{O}_{5}\right.$, and $\left.0.07 \% \mathrm{~K}_{2} \mathrm{O}\right)$ applied once per year in early spring (usually around March $19^{\text {th }}$ ). The soil was sampled each winter and summer at $0-1,2-3,7-8,17-18$, and 30-31 cm soil depth (10 replicas $* 5$ soil layers $=50$ samples $)$. The weeds were cut with a small hand-cutting machine and no heavy machinery was used as the space between trees does not allow heavy machinery to pass. Field-moist soil samples were sieved at $2 \mathrm{~mm}$ and stored at environmental temperatures; SOC content $\left(\mathrm{g} \mathrm{kg}^{-1}\right)$ was determined using the Walkley and Black (1934) method for the duration of the experiment. Soil bulk density was measured with the ring method.

\subsection{Data Analysis}

Soil organic carbon sequestration rate $\left(\mathrm{Mg} \mathrm{ha}^{-1} \mathrm{yr}^{-1}\right)$ for each soil layer was calculated as the ratio between SOC change during the long-term experiment and the duration (in years) of the experiment. The SOC stock difference between 1995 and 2016 was converted to $\mathrm{CO}_{2}$ using stoichiometric ratio $\mathrm{CO}_{2} / \mathrm{C}$ (3.667). After checking data normal distribution, statistical difference between the first (summer, 1995) and the last sampling data (winter, 2016) was checked by Tukey test for each sampling depth.

\section{Results and discussion}

\subsection{Soil organic carbon under organic farming}

Soil organic carbon stock in the $0-31 \mathrm{~cm}$ soil depth significantly increased after 21 years of organic farming management, ranging from $4.5 \mathrm{~g} \mathrm{~kg}^{-1}$ in 1995 to $9.7 \mathrm{~g} \mathrm{~kg}^{-1}$ in 2016 (Fig. 1). The highest SOC content increase was in the top soil layer $(0-1 \mathrm{~cm})$, ranging from $11.8 \pm 1.3 \mathrm{~g} \mathrm{~kg}^{-1}$ in 1995 to $55.3 \pm 8.8 \mathrm{~g} \mathrm{~kg}^{-1}$ in 2016 (Fig. 2). The first layer received more $\mathrm{C}$ input from litter, pruning residues, manure and spontaneous vegetation, leading to the large increase in SOC content. The rate of increase in SOC was lower during the first 5 years since organic farm conversion (Fig. 2). This suggests that the pruning residues and other organic inputs (weed biomass), which were not incorporated into the soil, need a period of about 5 years before they become part of the soil. After the first 5 years, the SOC showed a logarithmic increase in the first soil layer, which was not recorded in the deeper layer (Fig. 2). In addition, the soil under conventional farming had very few soil biota (Walmsley and Cerdà, 2017), which need time to recolonize the site that has been taken into organic production. This period of recolonization may also be the reason for the time lag of 5 years for change in SOC. 


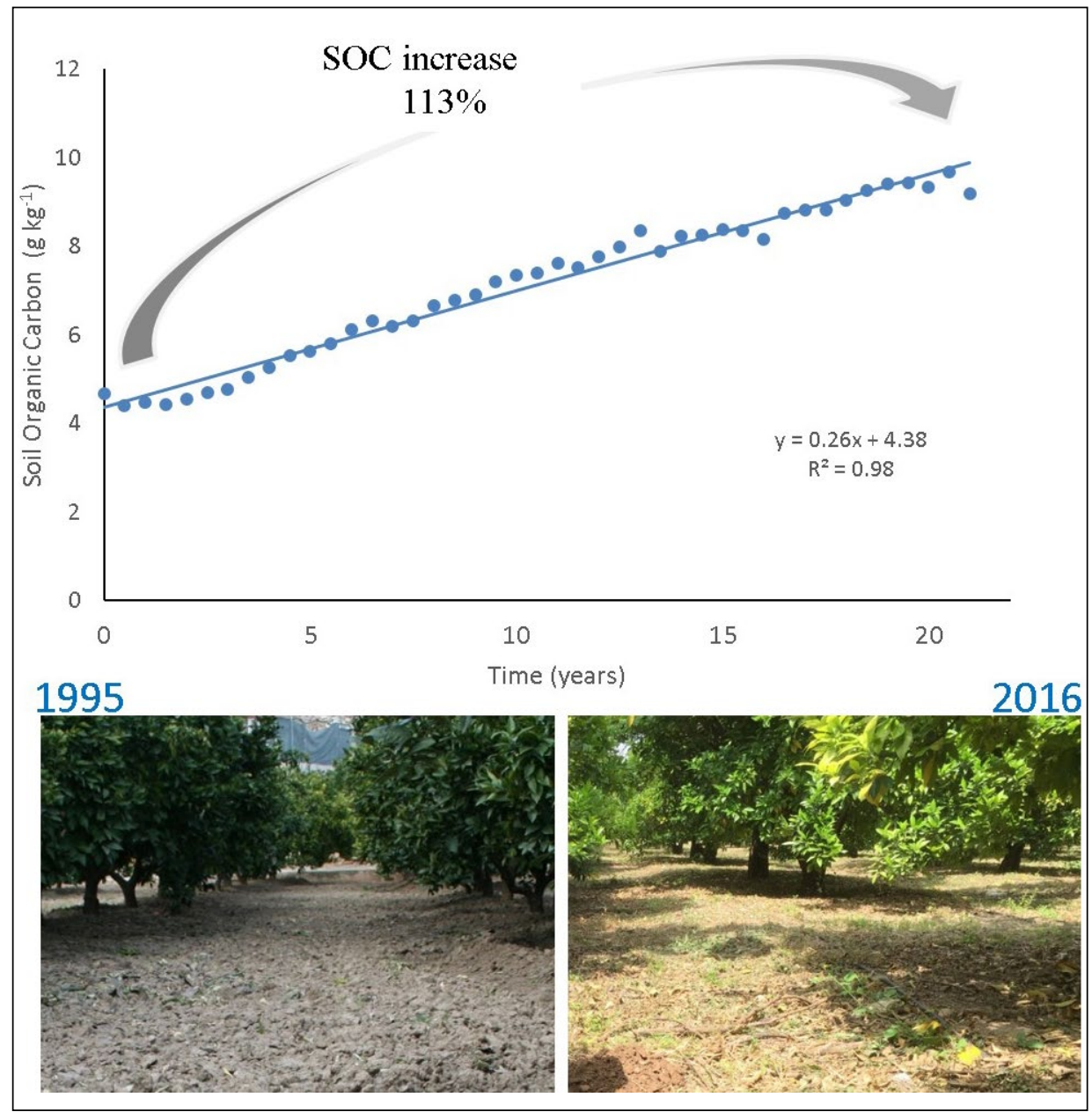

Figure 1. Soil organic carbon content ( $\mathrm{g} \mathrm{kg}-1$ ) during the long term experiment in $0-31 \mathrm{~cm}$ soil depth. Pictures of the citrus orchard in 1995 and 2016.

The effect of organic farming on SOC content over 21 years decreased with soil depth (Fig. 3). The increase of SOC was $126 \%$ in the $2-3 \mathrm{~cm}$ soil depth, $51 \%$ in the $7-8$ $\mathrm{cm}$ soil depth, and $53 \%$ at $17-18 \mathrm{~cm}$ soil depth. The SOC increase was not significantly different at $31 \mathrm{~cm}$ soil depth, although the SOC content slightly increased from $3.29 \pm$ $0.96 \mathrm{~g} \mathrm{~kg}^{-1}$ to $3.66 \pm 2.02 \mathrm{~g} \mathrm{~kg}^{-1}$ (Fig. 3). 


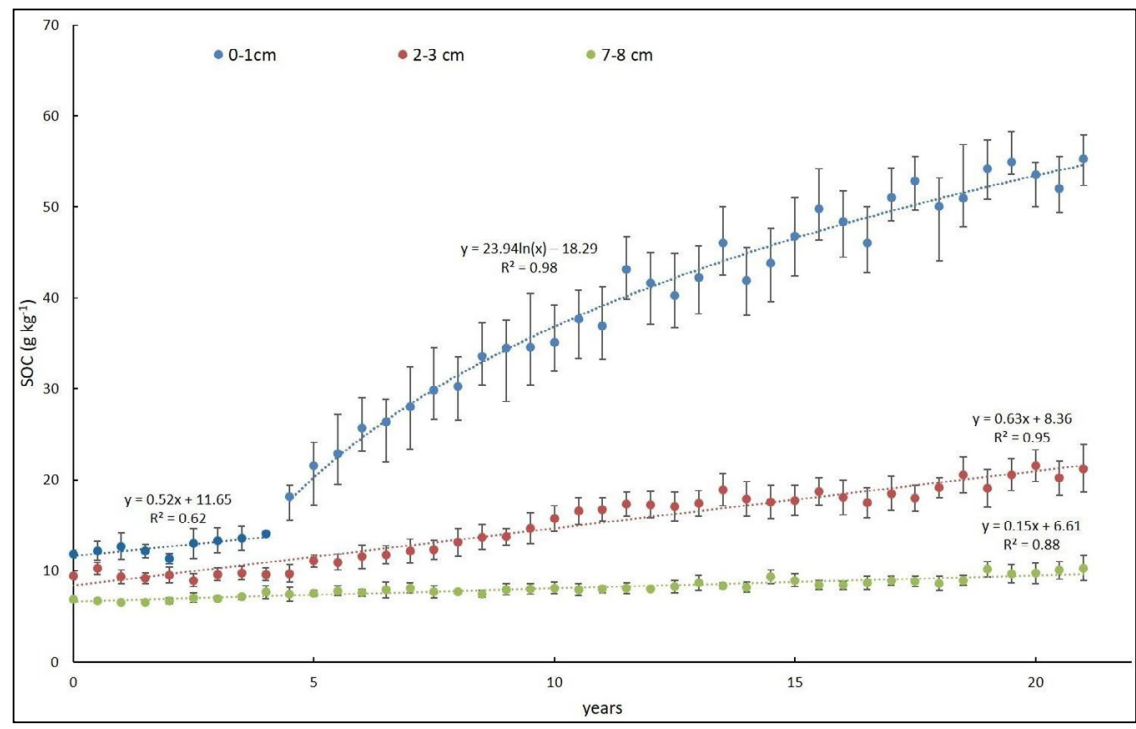

Figure 2. Soil organic carbon content in the top three soil layers $(0-1 \mathrm{~cm} ; 2-3 \mathrm{~cm}$ and $7-8 \mathrm{~cm})$ during 21 years of citrus organic farming. Bars indicate standard error $(n=10)$.

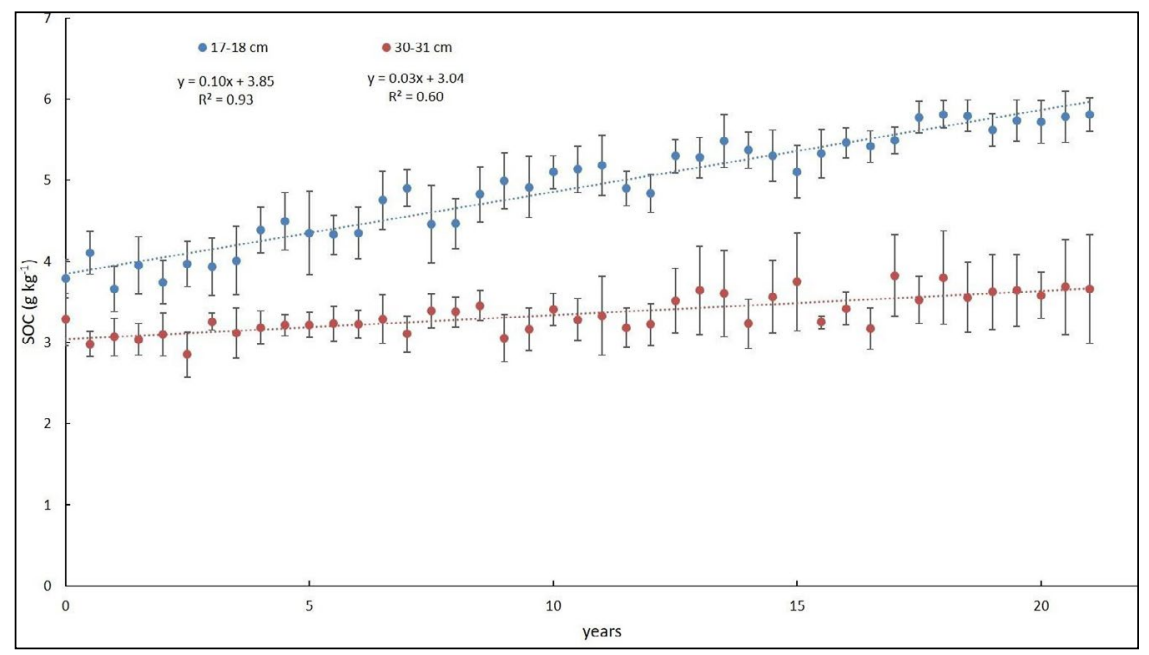

Figure 3. Soil organic carbon content in the deepest two soil layers $(17-18 \mathrm{~cm}$ and $30-31 \mathrm{~cm})$ during 21 years of citrus organic farming. Bars indicate standard error $(n=10)$.

\subsection{Effect of organic farming on soil bulk density}

Organic farming had a significant effect on soil bulk density in all soil layers, except for 30-31 cm soil depth (Fig. 4). After 21 years, the bulk density values 
decreased by $16 \%, 17 \%, 12 \%$ and $12 \%$ in $0-1 \mathrm{~cm}, 2-3 \mathrm{~cm}, 7-8 \mathrm{~cm}$ and $17-18 \mathrm{~cm}$ soil depths, respectively. These findings were consistent with several studies which demonstrated that organic matter decreases bulk density, due to a decrease of the denser mineral fraction, and due to an increase of aggregation and soil pores (Khaleel et al., 1981; Pagliai, 1988). However, the results of this study were in contrast with other long-term field experiments which found an increase in bulk density using alternative management due to no till. Several authors found that under no till management, soils had greater bulk density in comparison to conventional tillage, despite the fact that residues were left in the field (da Silva et al., 2001; Kushwaha et al., 2001). Our data showed an increase in the bulk density in the top layer in the first 5 years, during which time that the soil organic matter did not increase significantly (Fig. 3), and most likely the soil biota had not yet recovered. The soil in the top layer that was tilled for millennia is slightly compacted. This is also clearly observed in fields that are under no-tillage practice in combination with the use of herbicides (Di Prima et al., 2018). Here the bulk density increased, causing much lower infiltration capacity and higher runoff and erosion (Keesstra et al., 2016b). However, in the organically farmed site of our study, the soil was left untouched and fed with organic matter from the top. This is why the behaviour contrasts with tilled soils and has similar organic matter behaviour to forest soils (Adams, 1973; Ellert and Bettany, 1995; Périé and Ouimet, 2008).

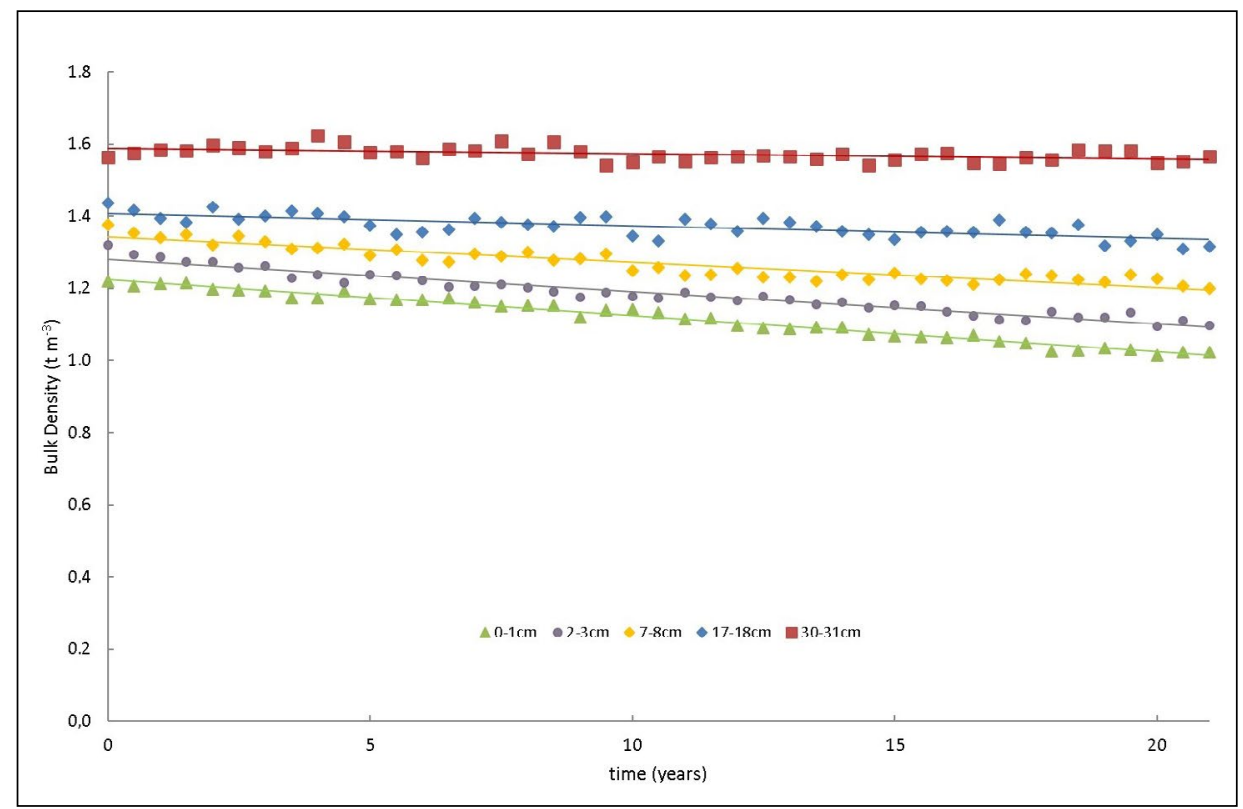

Figure 4. Evolution of soil bulk density in different soil layers. 


\subsection{Soil organic carbon stock and sequestration rate}

Over the whole 21-year period, $16.5 \mathrm{Mg} \mathrm{ha}^{-1}$ of organic carbon was sequestered into the soil, corresponding to a SOC sequestration rate of $0.78 \mathrm{Mg} \mathrm{C} \mathrm{ha-1}^{-1} \mathrm{y}^{-1}$ (Fig. 5). The same $\mathrm{C}$ sequestration rates were found in Mediterranean environments after the conversion from conventional to alternative soil management using cover cropping residues: for instance, in a meta-analysis (16 studies) Vicente-Vicente et al. (2016) found average values of $\mathrm{C}$ sequestration of $0.78 \mathrm{Mg} \mathrm{ha}^{-1} \mathrm{y}^{-1}$ after the conversion of orchard from conventional to cover crop soil management. In a meta-analysis (74 studies), Gattinger $e t$ al. (2012) found, on average, a C gain of $0.45 \pm 0.21 \mathrm{MgC} \mathrm{ha}^{-1} \mathrm{y}^{-1}$ for organic treatments in comparison to conventional management.

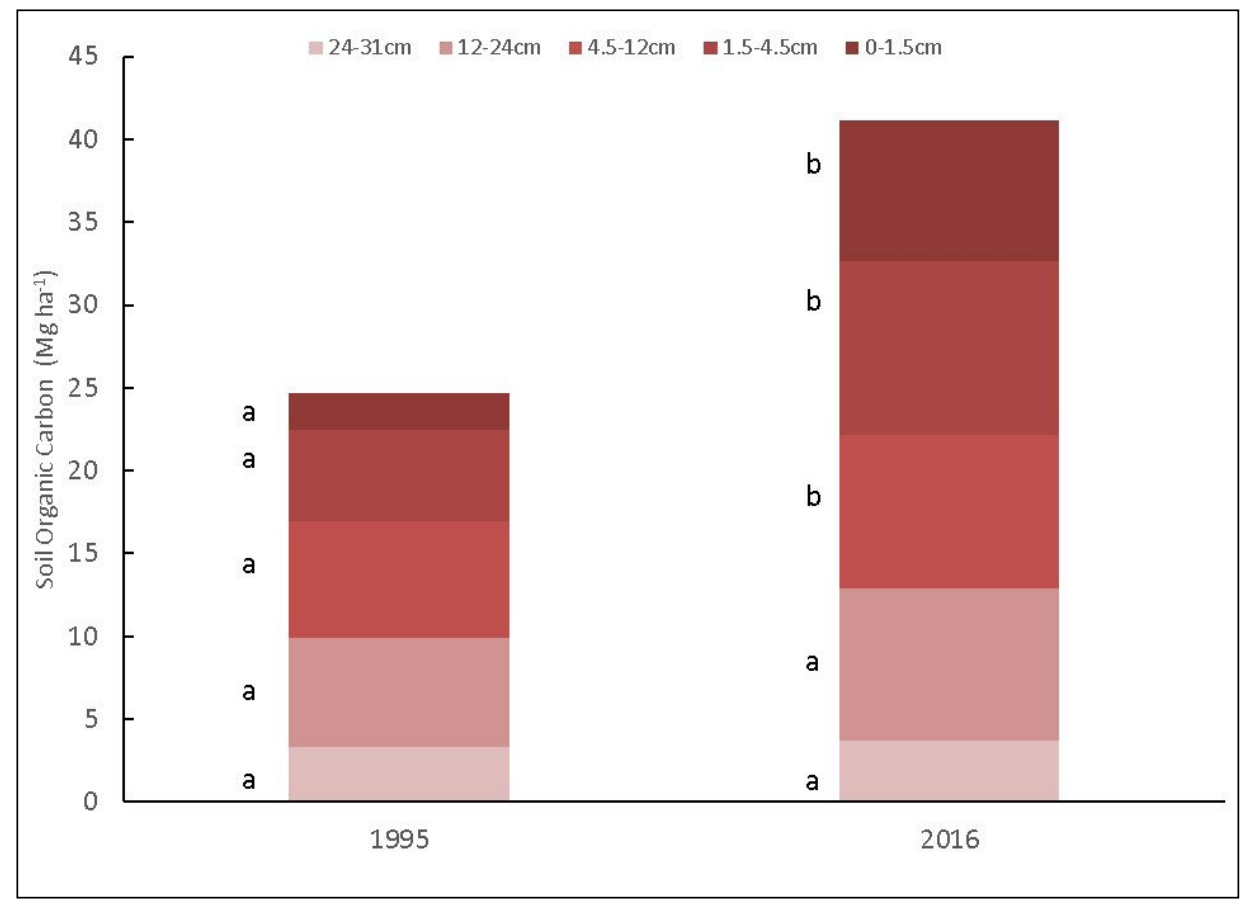

Figure 5. Soil organic carbon $\left(\mathrm{Mg} \mathrm{ha}^{-1}\right)$ stock in different soil layers. The same letter for each soil layer indicates no significant difference in SOC stock between the two dates (1995 and 2016).

The annual $C$ sequestration rate did not significantly change during the 21 years of observation in

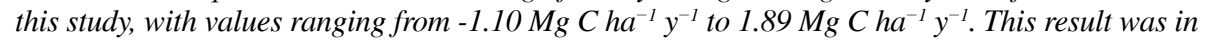
contrast with other studies carried out in semiarid environments, where an asymptotic trend of SOC stock in relation to time or C input was found (Gattinger et al., 2012; Novara et al., 2016). The linear increase of SOC under organic citrus management indicates that SOC steady state has not been reached and that the whole soil practices (residue, no till, and weed biomass residue) are still effectively contributing to SOC restoration and with continued carbon sequestration after 21 years.

The introduction of organic farming in citrus plantations resulted in an increase in SOC content, thereby contributing to greenhouse gas mitigation. After 
21 years, $61 \mathrm{Mg} \mathrm{CO}_{2}$ ha $^{-1}$ was sequestered and converted to long-lived SOC pools. Since the increase in SOC began to be seen after 5 years since land management change, studies of soil $\mathrm{C}$ change in Mediterranean environments should be longer than five years.

\subsection{The benefits of organic farming}

The experimental research conducted at the L'Alcoleja study site demonstrates that organic farming increases soil organic matter content and can sequester carbon from the atmosphere. But there is more. The scientific literature shows that organic farming also contributes to healthy soils due to the lowering of the bulk density such as found here. Other researchers found that organic farming contributes to increasing floral and faunal diversity. Hole et al. (2005) found that there is a clear benefit when organic farming is applied, and this varies among taxa (Fuller et al., 2005). This is also related to the improved natural fertility of the soil that allows for higher biodiversity, which leads to an improvement of the ecosystem services offered by the soil to human society (Winqvist et al., 2012).

More than fauna and flora, organic farming also offers a more diverse landscape. The research of Smith et al. (2010) showed that organic farming contributes to landscape heterogeneity and this is related to the landscape complexity, as Norton et al. (2009) found that there is a clear threshold when organic farming substitutes nonorganic farming. The impact of organic farming goes further when analysed from a holistic point of view. Pimentel et al. (2005) found that environmental, energetic and economic comparisons between organic and conventional farming systems show that organic farms are more sustainable. The impact of organic farming can also affect the quality of the products with higher nutritional quality, leading to better services to humankind (Worthington, 2001). The establishment of the organic farming must contribute to clean water, as all farming delivers nutrients to the soil and fluvial system (Pang and Letey, 2000; Schröder et al., 2004). Organic farming has similar environmental impacts as land abandonment. From the water resources point of view, there is more water intercepted (catch crops, grass covers) and more water use by the plants such as Lana-Renault et al. (2018) and Zuecco et al. (2018) demonstrated at catchment scale, and Cerdà et al.,(2018c) at plot scale. The benefits of organic farming are similar to the use of restoration strategies, such as Hueso-González et al. (2017) found in fire-affected land with the use of compost and with the use of chipped pruned branches and straw mulches.

\section{Conclusion}

Organic farming in citrus plantations is a significant strategy for SOC restoration and climate change mitigation. Although sequestration of SOC is more difficult in a Mediterranean environment due to the climatic conditions, results of a 21-years experiment showed a significant SOC increase in the first $0-31 \mathrm{~cm}$ of soil. Most of the organic matter was accumulated in the surface, as no-tillage took place in the orchard. There was a constant increase in SOC with an average of $0.78 \mathrm{Mg} \mathrm{C} \mathrm{ha}^{-1} \mathrm{y}^{-1}$ that finally resulted in $61 \mathrm{t} \mathrm{CO}_{2} \mathrm{ha}^{-1}$ sequestered over the research period. These findings provide a 
quantitative result for $\mathrm{C}$ accounting studies; and are helpful to address future policies on soil management.

\section{Acknowledgements}

This research was funded by the European Union Seventh Framework Program (FP7/2007- 2013) under grant no. 603498 (RECARE Project) and the research projects GL2008-02879/BTE and LEDDRA 243857.

\section{References}

Adams, W.A. 1973. The Effect of Organic Matter on the Bulk and True Densities of Some Uncultivated Podzolic Soils. Journal of Soil Science 24 (1), 10-17. https://doi. org/10.1111/j.1365-2389.1973.tb00737.x.

Álvaro-Fuentes, J., Plaza-Bonilla, D., Arrúe, J.L., Lampurlanés, J., Cantero-Martínez, C. 2014. Soil organic carbon storage in a no-tillage chronosequence under Mediterranean conditions. Plant and Soil 376 (1), 31-41. https://doi.org/10.1007/s11104-012-1167-x.

Argyropoulos, C., Tsiafouli, M.A., Sgardelis, S.P., Pantis, J.D. 2013. Organic farming without organic products. Land Use Policy 32, 324-328. https://doi.org/10.1016/j. landusepol.2012.11.008.

Averill, C., Turner, B.L., Finzi, A.C. 2014. Mycorrhiza-mediated competition between plants and decomposers drives soil carbon storage. Nature 505 (7484), 543-545. https://doi.org/10.1038/ nature 12901.

Benbrook, C., McCullum-Gómez, C. 2009. Organic vs Conventional Farming. Journal of the Academy of Nutrition and Dietetics 109 (5), 811. https://doi.org/10.1016/j.jada.2009.03.019.

Birkhofer, K., Bezemer, T.M., Bloem, J., Bonkowski, M., Christensen, S., Dubois, D., Ekelund, F., Fließbach, A., Gunst, L., Hedlund, K., Mäder, P., Mikola, J., Robin, C., Setälä, H., Tatin-Froux, F., Van der Putten, W.H., Scheu, S. 2008. Long-term organic farming fosters below and aboveground biota: Implications for soil quality, biological control and productivity. Soil Biology and Biochemistry 40 (9), 2297-2308 https://doi.org/10.1016/j. soilbio.2008.05.007.

Borrelli,P.,Paustian,K.,Panagos,P.,Jones,A.,Schütt,B.,Lugato,E.2016.Effect of Good Agricultural and Environmental Conditions on erosion and soil organic carbon balance: A national case study. Land Use Policy 50, 408-421 https://doi.org/10.1016/j.landusepol.2015.09.033.

Bowles, T.M., Acosta-Martínez, V., Calderón, F., Jackson, L.E. 2014. Soil enzyme activities, microbial communities, and carbon and nitrogen availability in organic agroecosystems across an intensively-managed agricultural landscape. Soil Biology and Biochemistry 68, 252-262. https://doi.org/10.1016/j.soilbio.2013.10.004.

Catalán, N., Marcé, R., Kothawala, D.N., Tranvik, L.J. 2016. Organic carbon decomposition rates controlled by water retention time across inland waters. Nature Geoscience 9 (7), 501-504 https://doi.org/10.1038/ngeo2720.

Cerdà, A., Morera, A.G., Bodí, M.B. 2009. Soil and water losses from new citrus orchards growing on sloped soils in the western Mediterranean basin. Earth Surface Processes and Landforms 34 (13), 1822-1830. https://doi.org/10.1002/esp.1889.

Cerdà, A., Rodrigo-Comino, J., Novara, A., Brevik, E.C., Vaezi, A.R., Pulido, M., GiménezMorera, A., Keesstra, S.D. 2018a. Long-term impact of rainfed agricultural land abandonment on soil erosion in the Western Mediterranean basin. Progress in Physical Geography: Earth and Environment 42 (2), 202-219. https://doi.org/10.1177/0309133318758521. 
Cerdà, A., Rodrigo-Comino, J., Giménez-Morera, A., Novara, A., Pulido, M., KapovićSolomun, M., Keesstra, S.D. 2018b. Policies can help to apply successful strategies to control soil and water losses. The case of chipped pruned branches (CPB) in Mediterranean citrus plantations. Land Use Policy 75, 734-745. https://doi.org/10.1016/j. landusepol.2017.12.052.

Cerdà, A., Rodrigo-Comino, J., Giménez-Morera, A., Keesstra, S.D. 2018c. Hydrological and erosional impact and farmer's perception on catch crops and weeds in citrus organic farming in Canyoles river watershed, Eastern Spain. Agriculture, Ecosystems \& Environment 258, 49-58. https://doi.org/10.1016/j.agee.2018.02.015.

Crittenden, S.J., Eswaramurthy, T., de Goede, R.G.M., Brussaard, L., Pulleman, M.M. 2014. Effect of tillage on earthworms over short- and medium-term in conventional and organic farming. Applied Soil Ecology 83, 140-148 https://doi.org/10.1016/j.apsoil.2014.03.001.

Crowder, D.W., Northfield, T.D., Strand, M.R., Snyder, W.E. 2010. Organic agriculture promotes evenness and natural pest control. Nature 466 (7302), 109-112. https://doi.org/10.1038/ nature09183.

Davidson, E.A., Janssens, I.A. 2006. Temperature sensitivity of soil carbon decomposition and feedbacks to climate change. Nature 440 (7081), 165-173. https://doi.org/10.1038/ nature04514.

Di Prima, S., Rodrigo-Comino, J., Novara, A., Iovino, M., Pirastru, M., Keesstra, S., Cerdà, A. 2018. Soil Physical Quality of Citrus Orchards Under Tillage, Herbicide, and Organic Managements. Pedosphere 28 (3), 463-477 https://doi.org/10.1016/S1002-0160(18)60025-6.

Ellert, B.H., Bettany, J.R. 1995. Calculation of organic matter and nutrients stored in soils under contrasting management regimes. Canadian Journal of Soil Science 75 (4), 529-538. https:// doi.org/10.4141/cjss95-075.

Fließbach, A., Oberholzer, H-R., Gunst, L., Mäder, P. 2007. Soil organic matter and biological soil quality indicators after 21 years of organic and conventional farming. Agriculture, Ecosystems \& Environment 118 (1), 273-284. https://doi.org/10.1016/j.agee.2006.05.022.

Fujisaki, K., Perrin, A-S., Desjardins, T., Bernoux, M., Balbino, L.C., Brossard, M. 2015. From forest to cropland and pasture systems: a critical review of soil organic carbon stocks changes in Amazonia. Global Change Biology 21 (7), 2773-2786. https://doi.org/10.1111/gcb.12906.

Fuller, R., Norton, L., Feber, R., Johnson, P., Chamberlain, D., Joys, A., Mathews, F., Stuart, R., Townsend, M., Manley, W., et al. 2005. Benefits of organic farming to biodiversity vary among taxa. Biology Letters 1 (4), 431-434. https://doi.org/10.1098/rsbl.2005.0357.

Gattinger, A., Muller, A., Haeni, M., Skinner, C., Fliessbach, A., Buchmann, N., Mäder, P., Stolze, M., Smith, P., El Hage Scialabba, N., Niggli, U. 2012. Enhanced top soil carbon stocks under organic farming. Proceedings of the National Academy of Sciences 109 (44), 18226-18231. https://doi.org/10.1073/pnas.1209429109.

Glover, J.D., Reganold, J.P., Andrews, P.K. 2000. Systematic method for rating soil quality of conventional, organic, and integrated apple orchards in Washington State. Agriculture, Ecosystems \& Environment 80 (1), 29-45. https://doi.org/10.1016/S0167-8809(00)00131-6.

Gruber, N., Galloway, J.N. 2008. An Earth-system perspective of the global nitrogen cycle. Nature 451 (7176), 293-296. https://doi.org/10.1038/nature06592.

Hole, D.G., Perkins, A.J., Wilson, J.D., Alexander, I.H., Grice, P.V., Evans, A.D. 2005. Does organic farming benefit biodiversity? Biological Conservation 122 (1), 113-130. https://doi. org/10.1016/j.biocon.2004.07.018.

Hondebrink, M.A., Cammeraat, L.H., Cerdà, A. 2017. The impact of agricultural management on selected soil properties in citrus orchards in Eastern Spain: A comparison between conventional and organic citrus orchards with drip and flood irrigation. Science of The Total Environment 581, 153-160. https://doi.org/10.1016/j.scitotenv.2016.12.087. 
Hueso-González, P., Martínez-Murillo, J.F., Ruiz-Sinoga, J.D. 2017. Benefits of straw and pinus mulch as forest management practices in Mediterranean forests. Cuadernos de Investigación Geográfica 43 (1), 189-208. https://doi.org/10.18172/cig.3142.

Kapović Solomun, M, Barger, N., Cerda, A., Keesstra, S., Marković, M. 2018. Assessing land condition as a first step to achieving land degradation neutrality: A case study of the Republic of Srpska. Environmental Science \& Policy 90, 19-27. https://doi.org/10.1016/j. envsci.2018.09.014.

Keesstra, S., Bouma, J., Wallinga, J., Tittonell, P., Smith, P., Cerdà, A., Montanarella, L., Quinton, J.N., Pachepsky, Y., van der Putten, W.H., et al. 2016a. The significance of soils and soil science towards realization of the United Nations Sustainable Development Goals. SOIL 2 (2), 111-128. https://doi.org/10.5194/soil-2-111-2016.

Keesstra, S., Pereira, P., Novara, A., Brevik, E.C., Azorin-Molina, C., Parras-Alcántara, L., Jordán, A., Cerdà, A. 2016b. Effects of soil management techniques on soil water erosion in apricot orchards. Science of The Total Environment 551-552, 357-366. https://doi.org/10.1016/j. scitotenv.2016.01.182.

Keesstra, S., Mol, G., de Leeuw, J., Okx, J., Molenaar, C., de Cleen, M., Visser, S. 2018. SoilRelated Sustainable Development Goals: Four Concepts to Make Land Degradation Neutrality and Restoration Work. Land 7 (4), 133. https://doi.org/10.3390/land7040133.

Keesstra, S., Rodrigo-Comino, J., Novara, A., Giménez-Morera, A., Pulido, M., Di Prima, S., Cerdà, A. 2019. Straw mulch as a sustainable solution to decrease runoff and erosion in glyphosate-treated clementine plantations in Eastern Spain. An assessment using rainfall simulation experiments. Catena 174, 95-103. https://doi.org/10.1016/j. catena.2018.11.007.

Khaleel, R., Reddy, K.R., Overcash, M.R. 1981. Changes in Soil Physical Properties Due to Organic Waste Applications: A Review 1. Journal of Environmental Quality 10 (2), 133 141. https://doi.org/10.2134/jeq1981.00472425001000020002x.

Kirchhoff, M., Rodrigo-Comino, J., Seeger, M., Ries, J.B. 2017. Soil erosion in sloping vineyards under conventional and organic land use managements (Saar-Mosel Valley, Germany). Cuadernos de Investigación Geográfica 43 (1), 119-140 https://doi.org/10.18172/cig.3161.

Kushwaha, C.P., Tripathi, S.K., Singh, K.P. 2001. Soil organic matter and water-stable aggregates under different tillage and residue conditions in a tropical dryland agroecosystem. Applied Soil Ecology 16 (3), 229-241. https://doi.org/10.1016/S0929-1393(00)00121-9.

Lana-Renault, N., López-Vicente, M., Nadal-Romero, E., Ojanguren, R., Llorente, J.A., Errea, P., Regués, D., Ruiz-Flaño, P., Khorchani, M., Arnáez, J., et al. 2018. Catchment based hydrology under post farmland abandonment scenarios. Cuadernos de Investigación Geográfica 44 (2), 503-534. https://doi.org/10.18172/cig.3475.

Lehmann, J., Kleber, M. 2015. The contentious nature of soil organic matter. Nature 528 (7580), 60-68. https://doi.org/10.1038/nature16069.

Liebig, M.A., Doran, J.W. 1999. Impact of Organic Production Practices on Soil Quality Indicators. Journal of Environmental Quality 28 (5), 1601-1609. https://doi.org/10.2134/ jeq1999.00472425002800050026x.

Lugato, E., Panagos, P., Bampa, F., Jones, A., Montanarella, L. 2014. A new baseline of organic carbon stock in European agricultural soils using a modelling approach. Global Change Biology 20 (1), 313-326. https://doi.org/10.1111/gcb.12292.

Macilwain, C. 2004. Organic: Is it the future of farming? Nature 428, 792-793. https://doi. org/10.1038/428792a.

Maeder, P., Fliessbach, A., Dubois, D., Gunst, L., Fried, P., Niggli, U. 2002. Soil Fertility and Biodiversity in Organic Farming. Science 296 (5573), 1694-1697 https://doi.org/10.1126/ science.1071148. 
Marinari, S., Mancinelli, R., Campiglia, E., Grego, S. 2006. Chemical and biological indicators of soil quality in organic and conventional farming systems in Central Italy. Ecological Indicators 6 (4), 701-711. https://doi.org/10.1016/j.ecolind.2005.08.029.

Michelsen, J. 2001. Recent Development and Political Acceptance of Organic Farming in Europe. Sociologia Ruralis 41 (1), 3-20. https://doi.org/10.1111/1467-9523.00167.

Montanaro, G., Xiloyannis, C., Nuzzo, V., Dichio, B. 2017. Orchard management, soil organic carbon and ecosystem services in Mediterranean fruit tree crops. Scientia Horticulturae 217, 92-101. https://doi.org/10.1016/j.scienta.2017.01.012.

Norton, L., Johnson, P., Joys, A., Stuart, R., Chamberlain, D., Feber, R., Firbank, L., Manley, W., Wolfe, M., Hart, B., Mathews, F., Macdonald, D., Fuller, R.J. 2009. Consequences of organic and non-organic farming practices for field, farm and landscape complexity. Agriculture, Ecosystems \& Environment 129 (1), 221-227. https://doi.org/10.1016/j.agee.2008.09.002.

Novara, A., Poma, I., Sarno, M., Venezia, G., Gristina, L. 2016. Long-Term Durum Wheat-Based Cropping Systems Result in the Rapid Saturation of Soil Carbon in the Mediterranean Semi-arid Environment. Land Degradation \& Development 27 (3), 612-619. https://doi. org/10.1002/ldr.2468.

Novara, A., Gristina, L., Sala, G., Galati, A., Crescimanno, M., Cerdà, A., Badalamenti, E., La Mantia, T. 2017. Agricultural land abandonment in Mediterranean environment provides ecosystem services via soil carbon sequestration. The Science of the Total Environment 576, 420-429. https://doi.org/10.1016/j.scitotenv.2016.10.123.

Novara, A., Minacapilli, M., Santoro, A., Rodrigo-Comino, J., Carrubba, A., Sarno, M., Venezia, G., Gristina, L. 2019. Real cover crops contribution to soil organic carbon sequestration in sloping vineyard. Science of The Total Environment 652, 300-306. https://doi.org/10.1016/j. scitotenv.2018.10.247.

Pagliai, M. 1988. Soil porosity aspects. International Agrophysics 4, 215-232.

Paleari, S. 2017. Is the European Union protecting soil? A critical analysis of Community environmental policy and law. Land Use Policy 64, 163-173. https://doi.org/10.1016/j. landusepol.2017.02.007.

Panagos, P., Imeson, A., Meusburger, K., Borrelli, P., Poesen, J., Alewell, C. 2016. Soil Conservation in Europe: Wish or Reality? Land Degradation \& Development 27 (6), 15471551. https://doi.org/10.1002/ldr.2538.

Pang, X.P., Letey, J. 2000. Organic Farming Challenge of Timing Nitrogen Availability to Crop Nitrogen Requirements. Soil Science Society of America Journal 64 (1), 247-253. https://doi. org/10.2136/sssaj2000.641247x.

Périé, C., Ouimet, R. 2008. Organic carbon, organic matter and bulk density relationships in boreal forest soils. Canadian Journal of Soil Science 88 (3), 315-325. https://doi.org/10.4141/ CJSS06008.

Pimentel, D., Hepperly, P., Hanson, J., Douds, D., Seidel, R. 2005. Environmental, Energetic, and Economic Comparisons of Organic and Conventional Farming Systems. BioScience 55 (7), 573-582. https://doi.org/10.1641/00063568(2005)055[0573:EEAECO]2.0.CO;2.

Reganold, J.P., Glover, J.D., Andrews, P.K., Hinman, H.R. 2001. Sustainability of three apple production systems. Nature 410 (6831), 926-930. https://doi.org/10.1038/35073574.

Rigby, D., Cáceres, D. 2001. Organic farming and the sustainability of agricultural systems. Agricultural Systems 68 (1), 21-40. https://doi.org/10.1016/S0308-521X(00)00060-3.

Schillaci, C., Acutis, M., Lombardo, L., Lipani, A., Fantappiè, M., Märker, M., Saia, S. 2017. Spatio-temporal topsoil organic carbon mapping of a semi-arid Mediterranean region: The role of land use, soil texture, topographic indices and the influence of remote sensing data to modelling. Science of The Total Environment 601-602, 821-832. https://doi.org/10.1016/j. scitotenv.2017.05.239. 
Schjønning, P., Elmholt, S., Munkholm, L.J., Debosz, K. 2002. Soil quality aspects of humid sandy loams as influenced by organic and conventional long-term management. Agriculture, Ecosystems \& Environment 88 (3), 195-214. https://doi.org/10.1016/S0167-8809(01)00161-X.

Schröder, J.J., Scholefield, D., Cabral, F., Hofman, G. 2004. The effects of nutrient losses from agriculture on ground and surface water quality: the position of science in developing indicators for regulation. Environmental Science \& Policy 7 (1), 15-23. https://doi. org/10.1016/j.envsci.2003.10.006.

Seufert, V., Ramankutty, N., Mayerhofer, T. 2017. What is this thing called organic? - How organic farming is codified in regulations. Food Policy 68, 10-20. https://doi.org/10.1016/j. foodpol.2016.12.009.

da Silva, A.P., Nadler, A., Kay, B. 2001. Factors contributing to temporal stability in spatial patterns of water content in the tillage zone. Soil and Tillage Research 58 (3-4), 207-218. https://doi.org/10.1016/S0167-1987(00)00169-0.

Skinner, C., Gattinger, A., Muller, A., Mäder, P., Fließbach, A., Stolze, M., Ruser, R., Niggli, U. 2014. Greenhouse gas fluxes from agricultural soils under organic and non-organic management - A global meta-analysis. Science of The Total Environment 468-469, 553 563. https://doi.org/10.1016/j.scitotenv.2013.08.098.

Smith, P. 2016. Soil carbon sequestration and biochar as negative emission technologies. Global Change Biology 22 (3), 1315-1324. https://doi.org/10.1111/gcb.13178.

Smith, H.G., Dänhardt, J., Lindström, Å., Rundlöf, M. 2010. Consequences of organic farming and landscape heterogeneity for species richness and abundance of farmland birds. Oecologia 162 (4), 1071-1079. https://doi.org/10.1007/s00442-010-1588-2.

Smith, P., Cotrufo, M.F., Rumpel, C., Paustian, K., Kuikman, P.J., Elliott, J.A., McDowell, R., Griffiths, R.I., Asakawa, S., Bustamante, M., House, J.I., Sobocká, J., Harper, R., Pan, G., West, P.C., Gerber, J.S., Clark, J.M., Adhya, T., Scholes, R.J., Scholes, M.C. 2015. Biogeochemical cycles and biodiversity as key drivers of ecosystem services provided by soils. SOIL 1 (2), 665-685. https://doi.org/10.5194/soil-1-665-2015

Soil Survey Staff. 2014. Keys to Soil Taxonomy, $12^{\text {th }}$ ed. USDA-Natural Resources Conservation Service, Washington DC.

Sommer, R., Bossio, D. 2014. Dynamics and climate change mitigation potential of soil organic carbon sequestration. Journal of Environmental Management 144, 83-87. https://doi. org/10.1016/j.jenvman.2014.05.017.

Vicente-Vicente, J.L., García-Ruiz, R., Francaviglia, R., Aguilera, E., Smith, P. 2016. Soil carbon sequestration rates under Mediterranean woody crops using recommended management practices: A meta-analysis. Agriculture, Ecosystems \& Environment 235, 204-214. https:// doi.org/10.1016/j.agee.2016.10.024.

Walkley, A., Black, I.A. 1934. An examination of the Degtjareff method for determining soil organic matter, and a proposed modification of the chromic acid titration method. Soil Science 37 (1), 29-38

Walmsley, A., Cerdà, A. 2017. Soil macrofauna and organic matter in irrigated orchards under Mediterranean climate. Biological Agriculture \& Horticulture 33 (4), 247-257. https://doi.or $\mathrm{g} / 10.1080 / 01448765.2017 .1336486$.

Wang, L., Wang, Y., Saskia, K., Artemi, C., Ma, B., Wu, F. 2018. Effect of soil management on soil erosion on sloping farmland during crop growth stages under a large-scale rainfall simulation experiment. Journal of Arid Land 10 (6), 921-931. https://doi.org/10.1007/ s40333-018-0016-z.

Winqvist, C., Ahnström, J., Bengtsson, J. 2012. Effects of organic farming on biodiversity and ecosystem services: taking landscape complexity into account. Annals of the New York Academy of Sciences 1249, 191-203. https://doi.org/10.1111/j.1749-6632.2011.06413.x. 
Novara et al.

Worthington, V. 2001. Nutritional quality of organic versus conventional fruits, vegetables, and grains. Journal of Alternative and Complementary Medicine (New York, N.Y.) 7 (2), 161-173. https://doi.org/10.1089/107628001300303691.

Zuecco, G., Penna, D., Borga, M. 2018. Runoff generation in mountain catchments: long-term hydrological monitoring in the Rio Vauz Catchment, Italy. Cuadernos de Investigación Geográfica 44 (2), 397-428. https://doi.org/10.18172/cig.3327. 